\title{
Polyphenolic and biological activities of leaves extracts of Argemone subfusiformis (Papaveraceae) and Urtica urens (Urticaceae)
}

\author{
Florence Jimoh $^{1}$, Adeolu Adedapo ${ }^{2 *}$, Adamu Aliero ${ }^{3}$ \& Anthony Afolayan ${ }^{1}$ \\ 1. Department of Botany, University of Fort Hare, Alice 5700, South Africa. \\ 2. Department of Veterinary Physiology, Biochemistry and Pharmacology, University of Ibadan, Nigeria; \\ adedapo3a@yahoo.co.uk \\ 3. Department of Botany, Usmanu Dan Fodiyo University, Sokoto, Nigeria. \\ * Corresponding author
}

Received 31-VIII-2009. C Corrected 20-IV-2010. Accepted 28-V-2010.

\begin{abstract}
Nowadays there is a resurgence of interest in wild plants for their possible medicinal value in diets, since some epidemiological studies have demonstrated their effectiveness against important diseases. Generally, foods of plant origin contain many bioactive compounds, proteins, energy, vitamins and specific minerals; in addition, the popular wild plant species provide fibre, essential fatty acids and enhance the taste and colour in diets. We studied the nutritional and medicinal potential of leaves of A. subfusiformis and U. urens, collected in Alice, South Africa in November 2006. To asses this we analyzed the phytochemical, antioxidant and antibacterial activities of leaves in acetone, methanol and water extracts, using standard analytical methods. The proximate analysis showed that the leaves of both plant species contained appreciable percentages of moisture; ashes; carbohydrates; crude proteins, lipids and fibres. Elemental analysis of macro and microelements showed higher values for $U$. urens that contained in decreasing order: iron $>$ manganese $>$ zinc $>$ copper $>$ calcium $>$ potassi um $>$ nitrogen $>$ magnesium $>$ phosphorus $>$ sodium, for $A$. subfusiformis resulted in iron $>$ zinc $>$ manganese $>$ coppe $\mathrm{r}>$ calcium $>$ potassium $>$ nitrogen $>$ magnesium $>$ phosphorus $>$ sodium. Besides, the chemical composition showed higher concentration of alkaloids, saponins and phytates in A. subfusiformis. The extracts also caused 1, 1diphenyl-2-picrylhydrazyl (DPPH) and 2, 2-azinobis-3 ethylbenzothiazoline-6-sulfonic acid (ABTS) radical scavenging activities which were comparable to those of ascorbic acid. The extracts of both plants contained appreciable levels of polyphenols and also caused varied inhibition of some bacterial strains used in this study. When the nutrient and chemical constituents of these plants were compared with recommended dietary allowance (RDA) values, the results revealed that the leaves contain an appreciable amount of nutrients, minerals, and phytochemicals and low levels of toxicants. Since the plants also exhibited some level of antibacterial activities, their use for medicinal purposes is to some extent being justified. Rev. Biol. Trop. 58 (4): 1517-1531. Epub 2010 December 01.
\end{abstract}

Key words: antibacterial, antioxidant, nutritional value, Argemone subfusiformis, Urtica urens.

Foods of plant origin contain many bioactive compounds in addition to conventionally identified nutrients such as proteins, energy, vitamins and specific minerals. More than 900 different phytochemicals have been identified as components of food and there may be more than 100 in just one vegetable (Akindahunsi \& Salawu 2005). Epidemiological studies have demonstrated that people eating vegetarian diets have a reduced risk of heart diseases and obesity (Bagchi \& Puri 1998).

Polyphenolic compounds are ubiquitous in foods of plant origin, and thus they constitute an integral part of the human diet (Bravo 1998). Interest in polyphenols has greatly increased recently because these phytochemicals are known to suppress rates of degenerative processes such as cardiovascular disorders and 
cancer (Bravo 1998, Duthie 2000, Huang et al. 2007). Some of these potential health benefits of polyphenolic substances, have been related to the action of these compounds as antioxidants, free radical scavengers, quenchers of singlet and triplet oxygen and inhibitors of peroxidation (Li-Chen et al. 2005). As a group, phenolic compounds have been found to be strong antioxidants against free radicals and other reactive oxygen species, the major cause of many chronic human diseases (Kyung-Hee et al. 2005, Chen \& Yen 2007).

A resurgence of interest has developed in wild species for their possible medicinal values in diets. Wild plant species provide minerals, fibre, vitamins and essential fatty acids and enhance taste and colour in diets. In addition, they have antibacterial, hepatoprotective and anticarcinogenic properties and therefore have medicinal values (Green 1992, Bianco et al. 1998, Yildrim et al. 2001).

It is interesting to note that few vegetables species are consumed in South Africa by the general public. The interview conducted during the course of our research, in Alice and its surrounding villages, indicated that many of these species, though known, are considered as weeds and were not eaten by the people (pers. comm.). This is in spite of the fact that these vegetables grow spontaneously and in abundance around the rural homesteads. Many workers (Lockeett et al. 2000, Akindahunsi \& Salawu 2005, Edeoga et al. 2006, Hassan \& Umar 2006, Ekop 2007) have reported the compositional evaluation and functional properties of various types of edible wild plants in use in the developing countries. The consumption of vegetables has also been linked to reduction in the incidence of oxidative-stress related diseases such as cancer, diabetes amongst others (Akubugwo et al. 2007). Some plant phenolics have also shown antimicrobial effects (Koduru et al. 2006).

Argemone subfusiformis Ownbey subsp. subfusiformis (Papaveraceae) has butter-yellow petals; seeds approximately $2 \mathrm{~mm}$ diameter and a capsule with fewer and larger spines. This plant also known as American poppy, is native to the Americas and Hawaii. Commonly found as a weed of roadsides, mining dumps, rabbit warrens, recently cultivated paddocks, waste places, and over grazed pastures. It often occurs as dense stands in sandy stream beds and alluvial flats associated with intermittent inland streams. A. subfusiformis contains isoquinoline alkaloids including sanguinarine, which causes mucosal irritation and also has interference with pyruvate oxidation in brain tissue. The sanguinarine is excreted in cows' milk and may be linked to the occurrence of endemic primary glaucoma in humans. The seeds of A. mexicana and A. ochroleuca are frequent contaminants of grain fed to chicken, causing low egg production, edema, ataxia, comb cyanosis and gastroenteritis. Dried plants in hay may cause chronic heart failure in cattle (Everist 1974, Auld \& Meld 1992; Wilson et al. 1995, Parsons \& Cuthbertson 2001, Harden 2002).

Urtica urens (dwarf nettle) is a member of the Urticaceae and native to Eurasia. Urtica prefers wet, rich soil and tends to grow in large patches. The stems are covered with stinging hairs but the leaves are smooth and more delicate (Wagner et al. 1994, Hirano et al. 1994, Schottner et al. 1997). The plant produces inconspicuous green-white flowers in late spring or summer. The leaf, flower, seed, and root of nettle are used differently and contain different chemical constituents. Like all green vegetables, nettle leaf is a micronutrient dense, nutritious food; however, it should be steamed or cooked before ingestion to destroy the stinging hairs, which contain histamine, formic acid, acetylcholine, acetic acid, butyric acid, leukotrienes, 5-hydroxytryptamine, and other irritants. Contact with the hairs leads to a mildly painful sting, development of an erythematous macule, and itching or numbness for a period lasting from minutes to days. Medicinal extracts of nettle do not cause this reaction as the hairs are destroyed in processing (Wagner et al. 1994, Hirano et al. 1994, Hryb et al. 1995, Berges et al. 1998).

These two plant species were identified as wild vegetables in South Africa and the study 
was therefore aimed at assessing their nutritional quality and possible biological activities.

\section{MATERIALS AND METHODS}

Plant collection and extract preparation: Fresh plant materials of Argemone subfusiformis and Urtica urens were collected in November 2006 from the wild around the University of Fort Hare campus, Alice, South Africa. The area falls within $30^{\circ} 0034^{\circ} 15^{\prime}$ $\mathrm{S}-22^{\circ} 45^{\prime} 30^{\circ} 15^{\prime} \mathrm{E}$. It is bounded by the sea in the East and the drier Karoo (semi-desert vegetation) in the West (Masika \& Afolayan 2003). These areas consist of villages which are generally classified as rural and poor. Professor D. Grierson of the Department of Botany, University of Fort Hare, authenticated the species, and a voucher specimen was prepared and deposited in the herbarium of the Department of Botany (Jimoh Med. 2006/7). The plant material was allowed to air-dry at ambient temperature $\left( \pm 24^{\circ} \mathrm{C}\right)$ and then milled. Twenty grams of dried plant samples were each extracted with $200 \mathrm{~mL}$ of acetone, methanol, and water, respectively, at ambient temperature, with agitation for 18-24h. Each extract was filtered using Whatman No. 1 filter paper, and concentrated under reduced pressure to dryness below $40^{\circ} \mathrm{C}$. The water extract was freeze-dried. The extract yields $(\mathrm{w} / \mathrm{w})$ were acetone $(2.5 \%)$, methanol $(7.9 \%)$, and water (9.3\%), respectively for A. subfusiformis but $2.7 \%$ (acetone), $8.7 \%$ (methanol) and $8.8 \%$ (water) respectively for $U$. urens. The dried extracts obtained were used directly for the determination of the antioxidant and antibacterial activities (Taylor et al. 1996). Determinations of chemical and nutritive values of these plants were carried out using the dried samples that were ground into powder.

Chemicals: 1,1-diphenyl-2-picrylhydrazyl (DPPH), 2,2'-azinobis-3-ethylbenzothiazoline6-sulfonic acid (ABTS), 3-(2-pyridyl)-5,6diphenyl-1,2,4-triazine-4',4"-disulfonic acid, Potassium Ferricyanide; Catechin, Butylated Hydroxytoluene (BHT), Ascorbic Acid, Tannic Acid, Quercetin and $\mathrm{FeCl}_{3}$ were purchased from Sigma Chemical Co. (St. Louis, MO, USA); vanillin from BDH, Folin-Ciocalteu's Phenol Reagent and Sodium Carbonate from Merck Chemical Supplies (Damstadt, Germany). All the other chemicals used including the solvents, were of analytical grade.

Proximate analysis: The recommended methods of the Association of Official Analytical chemists [AOAC 1999] were used for the determination of moisture, ash, crude lipid, crude fibre and nitrogen content.

Mineral analysis: The automated procedure for determining cations in plant materials utilizes the reaction between a particular cation and molybdovanate to form a complex. The complex is then measured colorimetrically at $420 \mathrm{~nm}$. The elements comprising sodium, calcium, potassium, magnesium, iron, zinc, copper, manganese, potassium, nitrogen and phosphorus were determined in this way.

Anti-nutrient analysis: Determination of alkaloid and saponins were as described by Obadoni \& Ochuko (2001). Phytate was estimated by the method of Wheeler \& Ferrel (1971).

Determination of total phenolics: Total Phenol contents in the extracts were determined by the modified Folin-Ciocalteu method (Wolfe et al. 2003). An aliquot of the extract was mixed with $5 \mathrm{ml}$ Folin-Ciocalteu reagent (previously diluted with water 1:10 v/v) and $4 \mathrm{ml}(75 \mathrm{~g} / \mathrm{l})$ of Sodium Carbonate. The tubes were mixed for $15 \mathrm{sec}$ and allowed to stand for $30 \mathrm{~min}$ at $40^{\circ} \mathrm{C}$ for color development. Absorbance was measured at $765 \mathrm{~nm}$ using the Hewlett Packard UV-VS spectrophotometer. Samples of extracts were evaluated at a final concentration of $0.1 \mathrm{mg} / \mathrm{ml}$. Total phenolic content were expressed as $\mathrm{mg} / \mathrm{g}$ tannic acid equivalent using the following equation based on the calibration curve: $\mathrm{y}=0.1216 \mathrm{x}, \mathrm{R}^{2}=0.9365$, where $x$ was the absorbance, and $y$ was the tannic acid equivalent $(\mathrm{mg} / \mathrm{g})$.

Determination of total flavonoids: Total flavonoids were estimated using the method 
of Ordoñez et al. (2006). A volume of $0.5 \mathrm{ml}$ of $2 \% \mathrm{AlCl}_{3}$ ethanol solution was added to $0.5 \mathrm{ml}$ of samples. After one hour at room temperature, the absorbance was measured at $420 \mathrm{~nm}$. A yellow color indicated the presence of flavonoids. Extract samples were evaluated at a final concentration of $0.1 \mathrm{mg} / \mathrm{mL}$. Total flavonoid content was calculated as quercetin $(\mathrm{mg} / \mathrm{g})$ using the following equation based on the calibration curve: $\mathrm{y}=0.0255 \mathrm{x}, \mathrm{R}^{2}=0.9812$, where $x$ was the absorbance and $y$ was the quercetin equivalent $(\mathrm{mg} / \mathrm{g})$.

Determination of total flavonols: Total flavonols in plant extracts were estimated using the method of Kumaran \& Karunakaran (2006). $2.0 \mathrm{~mL}$ of $2 \% \mathrm{AlCl}_{3}$ ethanol and $3.0 \mathrm{~mL}(50 \mathrm{~g} / \mathrm{L})$ sodium acetate solutions were added to $2.0 \mathrm{~mL}$ of the sample. The absorption at $440 \mathrm{~nm}$ was read after $2.5 \mathrm{~h}$ at $20^{\circ} \mathrm{C}$. Extract samples were evaluated at a final concentration of $0.1 \mathrm{mg} /$ ml. Total flavonoid content was calculated as quercetin $(\mathrm{mg} / \mathrm{g})$ using the following equation based on the calibration curve: $y=0.0255 x$, $\mathrm{R}^{2}=0.9812$, where $x$ was the absorbance and $y$ was the quercetin equivalent $(\mathrm{mg} / \mathrm{g})$.

Determination of total proanthocyanidins: Determination of proanthocyanidin was based on the procedure reported by Sun et al. (1998). A volume of $0.5 \mathrm{ml}$ of $0.1 \mathrm{mg} / \mathrm{ml}$ of extract solution was mixed with $3 \mathrm{ml}$ of $4 \%$ vanillin-methanol solution and $1.5 \mathrm{ml}$ hydrochloric acid; the mixture was allowed to stand for $15 \mathrm{~min}$. The absorbance was measured at 500nm. Extract samples were evaluated at a final concentration of $0.1 \mathrm{mg} / \mathrm{ml}$. Total proanthocyanidin content were expressed as catechin equivalents $(\mathrm{mg} / \mathrm{g}$ ) using the following equation based on the calibration curve: $\mathrm{y}=0.5825 \mathrm{x}, \mathrm{R}^{2}=0.9277$, where $x$ was the absorbance and $y$ was the catechin equivalent $(\mathrm{mg} / \mathrm{g})$.

\section{Determination of antioxidant activity}

DPPH radical scavenging assay: The effect of extracts on DPPH radical was estimated using the method of Liyana-Pathirana \& Shahidi (2003). A solution of $0.135 \mathrm{mM}$ DPPH in methanol was prepared and $1.0 \mathrm{ml}$ of this solution was mixed with $1.0 \mathrm{ml}$ of extract in methanol containing $0.02-0.1 \mathrm{mg}$ of the extract. The reaction mixture was mixed thoroughly and left in the dark at room temperature for $30 \mathrm{~min}$. The absorbance of the mixture was measured spectrophotometrically at $517 \mathrm{~nm}$. Ascorbic acid and BHT were used as references. The ability to scavenge DPPH radical was calculated by the following equation: DPPH radical scavenging activity $(\%)=\left[\left(\mathrm{Abs}_{\text {control }}-\mathrm{Abs}_{\text {sample }}\right)\right] /($ Abscontrol) $] \times 100$ where $\mathrm{Abs}_{\text {control }}$ is the absorbance of DPPH radical+methanol; $\mathrm{Abs}_{\text {sample }}$ is the absorbance of DPPH radical+sample extract/ standard.

ABTS radical scavenging assay: The method of Re et al. (1999) was adopted for this assay. The stock solutions included $7 \mathrm{mM}$ ABTS solution and $2.4 \mathrm{mM}$ Potassium persulfate solution. The working solution was then prepared by mixing the two stock solutions in equal quantities and allowing them to react for $12 \mathrm{~h}$ at room temperature in the dark. The solution was then diluted by mixing $1 \mathrm{ml}$ ABTS solution with $60 \mathrm{ml}$ methanol to obtain an absorbance of $0.706 \pm 0.001$ units at $734 \mathrm{~nm}$ using the spectrophotometer. Fresh ABTS solution was prepared for each assay. Plant extracts $(1 \mathrm{ml})$ were allowed to react with $1 \mathrm{ml}$ of the ABTS solution and the absorbance was taken at $734 \mathrm{~nm}$ after $7 \mathrm{~min}$ using the spectrophotometer. The ABTS scavenging capacity of the extract was compared with that of BHT, and the percentage inhibition calculated as ABTS radical scavenging activity $(\%)=\left[\left(\mathrm{Abs}_{\text {control }}-\mathrm{Abs}_{\text {sa- }}\right.\right.$ mple $)] /\left(\mathrm{Abs}_{\text {control })}\right] \mathrm{x} 100$ where $\mathrm{Abs}_{\text {control }}$ is the absorbance of ABTS radical+methanol; $\mathrm{Abs}_{\text {sa- }}$ mple is the absorbance of ABTS radical+sample extract/standard.

Total antioxidant activity (FRAP assay): A modified method of Benzie \& Strain (1996) was adopted for the FRAP assay. The stock solutions included $300 \mathrm{mM}$ Acetate buffer $(3.1 \mathrm{~g}$ $\mathrm{C}_{2} \mathrm{H}_{3} \mathrm{NaO}_{2} \cdot 3 \mathrm{H}_{2} \mathrm{O}$ and $16 \mathrm{ml} \mathrm{C}_{2} \mathrm{H}_{4} \mathrm{O}_{2}$ ), pH 3.6, $10 \mathrm{mM}$ TPTZ (2,4,6-tripyridyl-s-triazine) solution in $40 \mathrm{mM} \mathrm{HCl}$, and $20 \mathrm{mM} \mathrm{FeCl} \cdot 6 \mathrm{H}_{2} \mathrm{O}$ solution. The fresh working solution was 
prepared by mixing $25 \mathrm{ml}$ acetate buffer, $2.5 \mathrm{ml}$ TPTZ, and $2.5 \mathrm{ml} \mathrm{FeCl}_{3} \cdot 6 \mathrm{H}_{2} \mathrm{O}$. The temperature of the solution was raised to $37^{\circ} \mathrm{C}$ before using. Plant extracts $(150 \mu \mathrm{L})$ were allowed to react with $2850 \mu \mathrm{L}$ of the FRAP solution for $30 \mathrm{~min}$ in a dark condition. Readings of the colored product (ferrous tripyridyltriazine complex) were taken at $593 \mathrm{~nm}$. The standard curve was linear between 200 and $1000 \mu \mathrm{M} \mathrm{FeSO}_{4}$. Results are expressed in $\mu \mathrm{M} \mathrm{Fe}$ (II)/g dry mass and compared with that of BHT, ascorbic acid and catechin.

Antibacterial assay: The bacterial cultures used in this study were obtained from the Department of Biochemistry and Microbiology, Rhodes University, South Africa. They consisted of five Gram-positive and five Gramnegative strains (Tables 6 and 7). Each organism was maintained on nutrient agar plates and was recovered for testing by growth in nutrient broth for $24 \mathrm{hr}$. Before use, each bacterial culture was diluted 1:100 with fresh sterile nutrient broth (Afolayan \& Meyer 1997).

Test organisms were streaked in a radial pattern on sterile nutrient agar plates containing filtered extracts at final concentrations of $0.1,0.5,1.0,2.5$ and $5.0 \mathrm{mg} / \mathrm{ml}$ (Koduru et al. 2006). Plates containing only nutrient agar and another set containing nutrient agar and the respective solvents served as controls. Streptomycin and chloramphenicol served as standard. After inoculation, the plates were incubated at $37^{\circ} \mathrm{C}$ for 24 to $48 \mathrm{~h}$. Each treatment was performed in triplicate and complete inhibition of

TABLE 1

Proximate analysis of the leaves of Argemone subfusiformis and Urtica urens

$\begin{array}{lcc}\text { Constituents } & \begin{array}{c}\text { Argemone } \\ \text { subfusiformis }\end{array} & \begin{array}{c}\text { Urtica } \\ \text { urens }\end{array} \\ \text { Moisture } & 72.80 \pm 8.96 & 57.16 \pm 2.18 \\ \text { Ash } & 14.5 \pm 0.00 & 27.75 \pm 0.25 \\ \text { Protein } & 19.19 \pm 0.24 & 18.36 \pm 0.10 \\ \text { Fat } & 5.5 \pm 0.01 & 7.25 \pm 0.25 \\ \text { Carbohydrate } & 36.69 \pm 0.30 & 30.29 \pm 0.4 \\ \text { Crude fibre } & 21.13 \pm 0.7 & 16.08 \pm 0.76 \\ \text { Energy (kcal) } & 285.02 \pm 0.20 & 260.93 \pm 0.1\end{array}$

bacterial growth was required for an extract to be declared bioactive.

The experimental results were expressed as mean \pm standard deviation (SD) of three replicates. When applicable, the data were subjected to one way analysis of variance (ANOVA) and differences between samples were determined by Duncan's Multiple Range test using the Statistical Analysis System (SAS 1999) program. $p$ values $<0.05$ were regarded as significant.

\section{RESULTS}

Proximate analysis: The proximate analysis expressed in percentages, showed the moisture, ash, crude protein, crude lipid, crude fibre and carbohydrate contents in leaves of $A$. subfusiformis as 72.8, 14.5, 19.2, 5.5, 21.1 and $36.7 \%$, respectively, while its calorific value is $285.0 \mathrm{Kcal} / 100 \mathrm{~g}$. In the case of $U$. urens, analysis showed the moisture, ash, crude protein, crude lipid, crude fibre and carbohydrate content of the leaves as 57.2, 27.8, 18.4, 7.3, 16.1 and $30.3 \%$, respectively, while its calorific value is $260.9 \mathrm{Kcal} / 100 \mathrm{~g}$ (Table 1 ).

Macro and microelements analysis: Elemental analysis in $\mathrm{mg} / 100 \mathrm{~g}$ (DW) indicated that leaves of A. subfusiformis contained the following ordered from higher to lower concentrations: iron (396), zinc (72), manganese (71), copper (17), calcium (4.8), potassium (3.2), nitrogen (3.1), magnesium (0.7), phosphorus (0.3), and sodium (0.09). Furthermore, leaves of $U$. urens contained iron (839), manganese (104), zinc (55), copper (13), calcium (12.3), potassium (3.3), nitrogen (2.3), magnesium (0.7), phosphorus (0.5) and sodium (0.09) (Table 2).

Antinutrient analysis: The chemical composition in $\mathrm{mg} / 100 \mathrm{~g}$ (DW) for alkaloid, saponins, and phytate were 2.4, 5.8 and 4.3 respectively for $A$. subfusiformis. In the case of $U$. urens, these values were alkaloids (0.6), saponins (3.3) and phytate (4.4) (Table 3).

Polyphenols: For A. subfusiformis, the acetone and methanol extracts showed higher 
TABLE 2

Macro and micro elements constituents of leaves of Argemone subfusiformis and Urtica urens

$\begin{array}{lcc}\begin{array}{l}\text { Macro and micro } \\ \text { elements }(\mathrm{mg} / 100 \mathrm{~g} \mathrm{dwb})\end{array} & \begin{array}{c}\text { Argemone } \\ \text { subfusiformis }\end{array} & \begin{array}{c}\text { Urtica } \\ \text { urens }\end{array} \\ \text { Calcium } & 4.787 & 12.262 \\ \text { Copper } & 17 & 13 \\ \text { Iron* } & 396 & 839 \\ \text { Magnesium } & 0.663 & 0.683 \\ \text { Manganese } & 71 & 104 \\ \text { Phosphorus } & 0.272 & 0.463 \\ \text { Potassium } & 3.218 & 3.251 \\ \text { Sodium } & 0.094 & 0.092 \\ \text { Total Khedjal Nitrogen } & 3.07 & 2.98 \\ \text { Zinc } & 72 & 55 \\ \text { *Iron= ppm. } & & \end{array}$

TABLE 3

Analysis of anti-nutrients contents of Argemone subfusiformis and Urtica urens

$\begin{array}{lcc}\text { Anti-nutrients } & \begin{array}{c}\text { Argemone } \\ \text { subfusiformis }\end{array} & \text { Urtica urens } \\ \text { Alkaloids } & 2.35 \pm 0.35 & 0.58 \pm 0.03 \\ \text { Saponins } & 5.75 \pm 0.2 & 3.25 \pm 0.1 \\ \text { Phytate } & 4.30 \pm 0.61 & 4.39 \pm 1.10\end{array}$

concentrations of polyphenols than the water extract; whereas for $U$. urens, the methanol extract had greater content of total polyphenol than its acetone and water counterparts. In the case of flavonoids, acetone extract (1.22) resulted higher than water (0.63) and methanol (0.35) for A. subfusiformis, whereas for $U$. urens the flavonoids contents of acetone extract $(0.89)$ was higher than methanol $(0.46)$ and water (0.36) ones (Table 4).

Flavonols: The results for flavonols showed no difference for the acetone and methanol extracts of A. subfusiformis, though they were higher than those for the water extract. In the case of $U$. urens, the methanol extract had greater content of flavonols than the other two extracts. For proanthocyanidins, the acetone extracts of A. subfusiformis and $U$. urens were upper than those of methanol; besides, the acetone extract of $U$. urens was considerably high (8.12) (Table 4).

DPPH: At $1 \mathrm{mg} / \mathrm{ml}$, the acetone, methanol, water extracts and BHT caused DPPH radical scavenging activity at 84.9, 92.3, 69.5 and 99.3\% respectively for A. subfusiformis, while for $U$. urens (at $1 \mathrm{mg} / \mathrm{ml}$ ) results were 60.8 , 91.2, 63.5 and $100 \%$ for acetone, methanol, water and ascorbic acid respectively (Figs. 1 A \& B).

ABTS: At $1 \mathrm{mg} / \mathrm{ml}$, the acetone extract of A. subfusiformis caused $98.2 \%$ ABTS radical scavenging inhibition while the methanol, water extracts and BHT caused inhibition at 99.4, 95.9 and $99.3 \%$, respectively. For $U$. urens at the same concentration, the results were 97.5,

TABLE 4

Total polyphenol and flavonol contents of the acetone, methanol and water extracts of the leaves of Argemone subfusiformis and Urtica urens $(n=3, X \pm S E M)$

\begin{tabular}{lcccccc}
\multicolumn{1}{c}{ Phenolics } & \multicolumn{3}{c}{ Argemone subfusiformis } & \multicolumn{3}{c}{ Urtica urens } \\
& Acetone & Methanol & Water & Acetone & Methanol & Water \\
Total polyphenol & $14.97 \pm 0.46$ & $14.0 \pm 0.89$ & $6.18 \pm 0.27 *$ & $7.28 \pm 0.23^{*}$ & $14.42 \pm 0.51$ & $4.58 \pm 1.40^{*}$ \\
Flavonoids & $1.22 \pm 0.03$ & $0.35 \pm 0.12^{*}$ & $0.63 \pm 0.01$ & $0.89 \pm 0.08$ & $0.46 \pm 0.02$ & $0.36 \pm 0.03^{*}$ \\
Proanthocyanidins & $3.36 \pm 0.06^{*}$ & $2.36 \pm 0.40^{*}$ & $0.61 \pm 0.10^{*}$ & $8.12 \pm 0.36$ & $4.57 \pm 1.12$ & $2.92 \pm 0.38^{*}$ \\
Total Flavonol & $0.90 \pm 0.03$ & $0.97 \pm 0.45$ & $0.43 \pm 0.14^{*}$ & $0.81 \pm 0.01$ & $1.11 \pm 0.35$ & $0.71 \pm 0.02$
\end{tabular}

Total polyphenol is expressed as mg tannic acid/g of dry plant material.

Flavonoid is expressed as mg quercetin/g of dry plant material.

Proanthocyanidins is expressed as $\mathrm{mg}$ catechin/g of dry plant material.

Total flavonol is expressed as mg quercetin/g of dry plant material.

* Indicates that this value is significantly different from the other at $\mathrm{p}<0.05$. 


\section{A DPPH radical scavenging activity of $A$. subfusiformis}

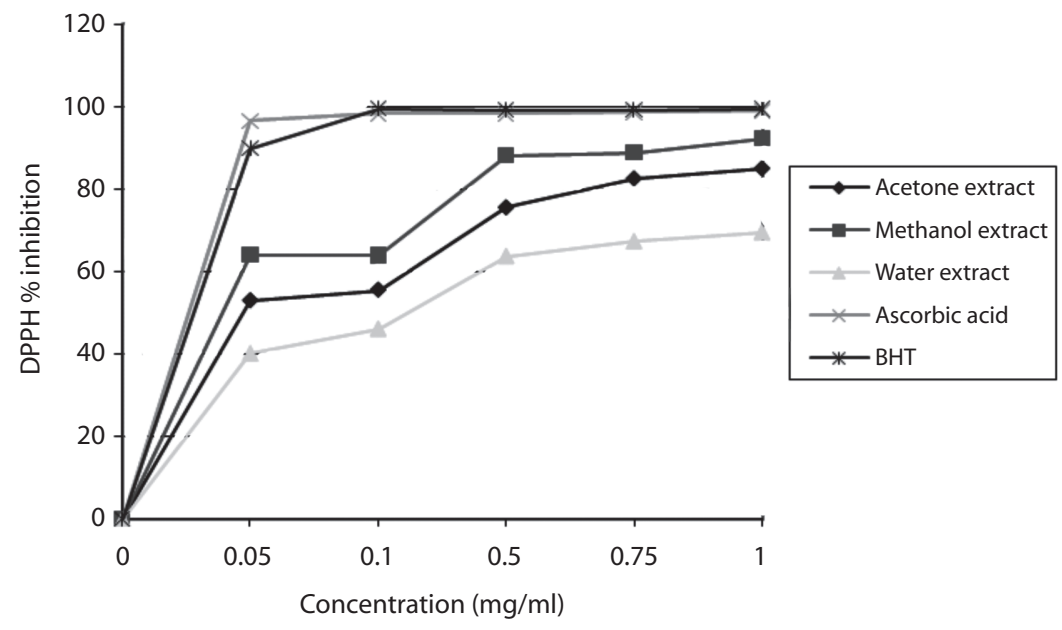

B DPPH radical scavenging activity of U.urens

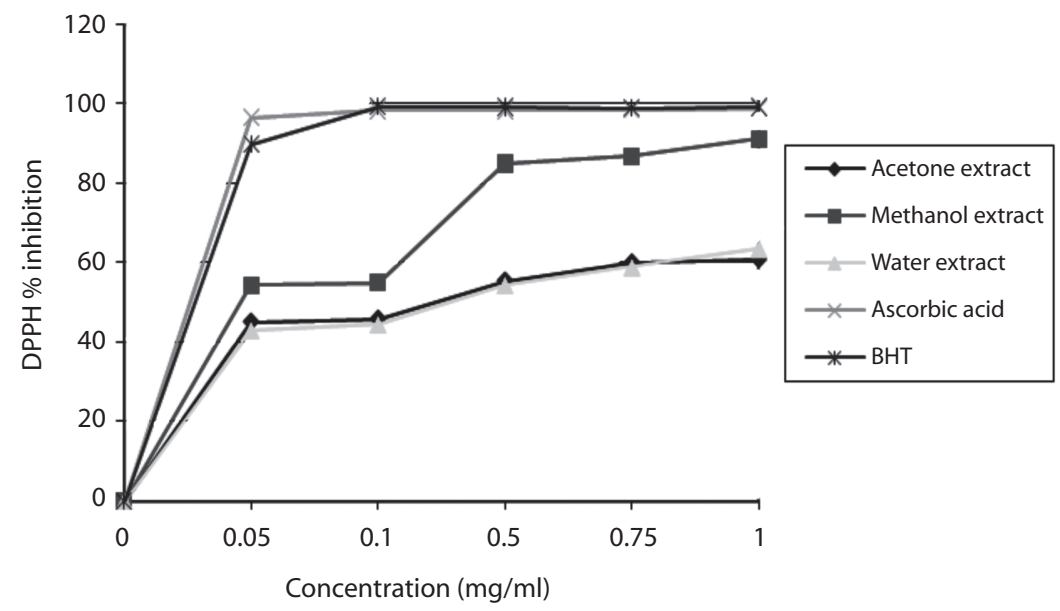

Fig. 1. (A) DPPH radical scavenging activities of Argemone subfusiformis and (B) DPPH radical scavenging activities of Urtica urens.

95.2, 98.5 and $99.3 \%$ for acetone, methanol, water and BHT respectively. At $0.5 \mathrm{mg} / \mathrm{ml}$, the percentage inhibition for methanol extract of U. urens was 99.5 (Fig. 2 A \& B).

FRAP: The acetone and methanol extracts of both plants had higher ferrous reducing antioxidant power (FRAP), when compared to that of water extract and BHT, but less activity compared to catechin, ascorbic acid and quercetin (Table 5).

Antibacterial assay: The acetone extract of A. subfusiformis has activity against all the 
A $\quad$ ABTS radical scavenging activity of $A$. subfusiformis

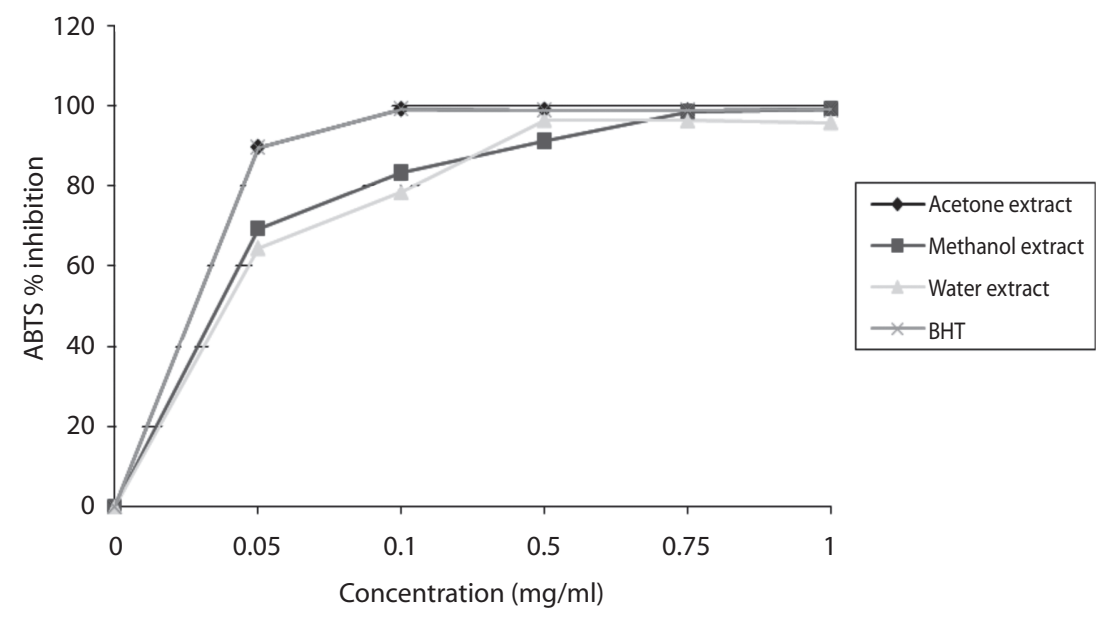

B $\quad$ ABTS radical scavenging activity of $U$. urens

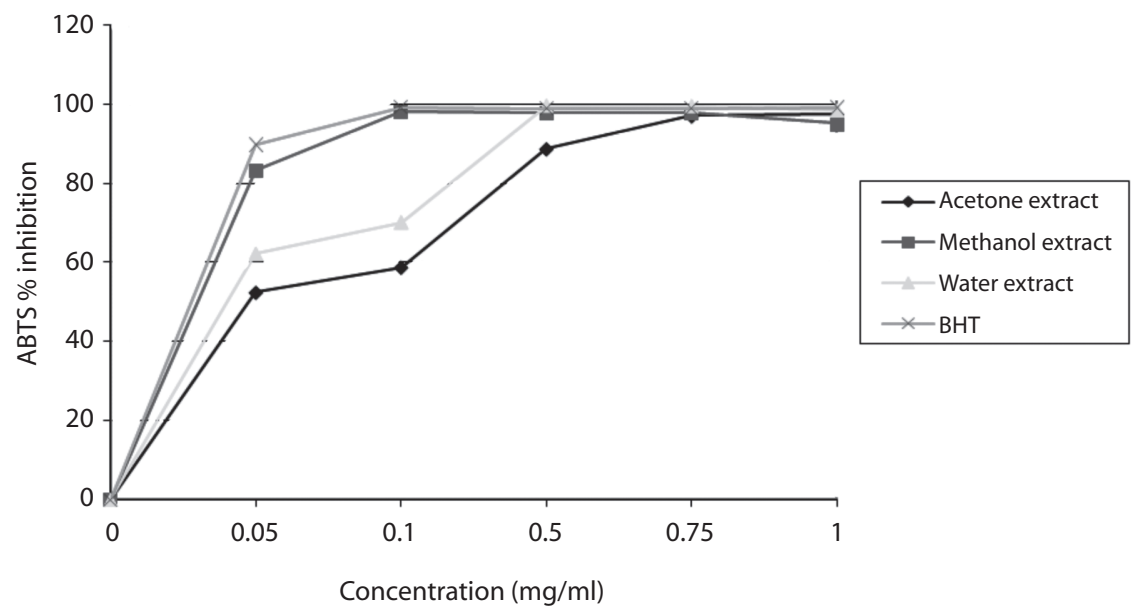

Fig. 2. (A) ABTS scavenging activities of Argemone subfusiformis and (B) ABTS scavenging activities of Urtica urens.

Gram positive organisms except Staphylococcus aureus. It was also active against two Gram negative organisms i.e. Escherichia coli and Salmonella pooni. The methanol extract was active against three gram positive organisms and one Gram negative organisms used in this study. The water extract of $A$. subfusiformis however showed activity against all the Gram positive organisms as well as two Gram negative strains used in this study. The acetone extract of $U$. urens showed activity against Bacillus cereus, Staphylococcus epidermidis, Staphylococcus aureus and E. coli. The water extract showed activity against all Gram positive strains except Streptococcus pyrogens. The methanol extract of $U$. urens was active against four Gram positive and one Gram negative strains. The water extract was the 
TABLE 5

FRAP activity of the acetone, methanol and water extracts of Argemone subfusiformis and Urtica urens

$\begin{array}{lcc}\text { Extracts/Standards } & \begin{array}{c}\text { Argemone } \\ \text { subfusiformis }\end{array} & \text { Urtica urens } \\ \text { Acetone } & 487.73 \pm 29.46 & 248.39 \pm 5.73 \\ \text { Methanol } & 175.44 \pm 13.2 & 90.57 \pm 13.65 \\ \text { Water } & 13.43 \pm 1.38 & 18.77 \pm 3.01 \\ \text { Ascorbic acid } & 1632.1 \pm 16.95 & 1632.1 \pm 16.95 \\ \text { BHT } & 63.46 \pm 2.49 & 63.46 \pm 2.49 \\ \text { Catechin } & 972.02 \pm 0.61 & 972.02 \pm 0.61 \\ \text { Quercetin } & 3107.29 \pm 31.28 & 3107.29+31.28\end{array}$

FRAP is expressed in units of $\mu \mathrm{mol} \mathrm{Fe}$ (II)/g.

most active since it had activity against all the organisms used in this study and even at the lowest concentration $(0.1$ and $1.0 \mathrm{mg} / \mathrm{ml})$ (Tables 6 and 7).

\section{DISCUSSION}

Proximate analysis: The results of proximate composition of the leaves of $A$. subfusiformis $(72.8 \%)$ and $U$. urens $(57.2 \%)$ showed relatively low moisture content. This is below the reported range (81.4-90.3\%) in some Nigerian green leafy vegetables (Akubugwo et al. 2007). Ash content, which is an index of mineral contents in biota, is $14.5 \mathrm{DW}$ in A. subfusiformis and $27.8 \% \mathrm{DW}$ in $U$. urens. These compare favourably with the values reported for Ipomea batatas (11.10\%), Vernonia colorata $(15.86 \%)$ and Moringa oleifera $(15.09 \%$ DW) (Lockeett et al. 2000, Antia et al. 2006). The value for $U$. urens is also, higher than that of some Nigerian leafy vegetable such as Ocimum gratissium (18.00\% DW) and Hibiscus esculentus $(8.00 \%$ DW) (Akindahunsi \& Salawu 2005). The crude protein content of A. subfusiformis $(19.2 \% \mathrm{DW})$ and $U$. urens $(18.4 \%)$ are greater than protein content of Momordica foecide (4.6\%) leaves consumed in Nigeria and Swaziland (Ogle \& Grivetti 1985, Isong \& Idiong 1997, Hassan \& Umar 2006). According to Pearson (1976), plant food that provides more than $12 \%$ of its calorific value is considered good source of protein. Therefore, the protein content of the leaves of these two plants will go a long way in meeting the protein requirement of the local people.

The crude lipid content of A. subfusiformis $(5.5 \% \mathrm{DW})$ and $U$. urens $(7.3 \% \mathrm{DW})$ resulted slightly lower than reported values (8.3-27.0\% DW) in some vegetables consumed in West Africa (Ifon \& Bassir 1980, Sena et al. 1998). However, it compares favorably with 4.2\% reported for Calchorus africanum leaves and $1.85-8.71 \%$ DW in some edible green leafy vegetables of Southern India and Nigeria (Agbo 2004, Gupta et al. 2005). The carbohydrate content of A. subfusiformis (36.7\% DW) and $U$. urens $(30.3 \% \mathrm{DW})$ is higher than 20 and $23.7 \%$ reported for Senna obtusfolia and Amaranthus incurvatus leaves, respectively

TABLE 6

Antibacterial activity of leaves extracts of Argemone subfusiformis (A.s.)

\begin{tabular}{|c|c|c|c|c|c|c|}
\hline \multirow{2}{*}{ Bacterial species } & \multirow{2}{*}{ Gram +/- } & \multicolumn{5}{|c|}{ Minimum inhibitory concentration (mg/ml) } \\
\hline & & Acetone & Methanol & Water & Chloramphenicol & Streptomycin \\
\hline Bacillus cereus & + & 1.0 & 2.0 & 1.0 & $<2$ & $<2$ \\
\hline Staphylococcus epidermidis & + & 1.0 & na & 1.0 & $<2$ & $<2$ \\
\hline Staphylococcus aureus & + & na & na & 1.0 & $<2$ & $<2$ \\
\hline Micrococcus kristinae & + & 2.0 & 2.0 & 1.0 & $<2$ & $<2$ \\
\hline Streptococcus pyrogens & + & 5.0 & 5.0 & 1.0 & $<2$ & $<2$ \\
\hline Escherischia coli & - & 5.0 & 5.0 & na & $<2$ & $<2$ \\
\hline Salmonella pooni & - & 5.0 & na & 1.0 & $<2$ & $<2$ \\
\hline Serratia marcescens & - & na & na & 1.0 & $<2$ & $<2$ \\
\hline Pseudomonas aeruginosa & - & na & na & na & $<20$ & $<5$ \\
\hline Klebsiella pneumonae & - & na & na & na & $<2$ & $<2$ \\
\hline
\end{tabular}


TABLE 7

Antibacterial activity of leaves extracts of Urtica urens

\begin{tabular}{lcccccc} 
Bacterial species & Gram + /- & \multicolumn{6}{c}{ Minimum inhibitory concentration (mg/ml) } \\
& & Acetone & Methanol & Water & Chloramphenicol & Streptomycin \\
Bacillus cereus & + & 2.0 & 5.0 & 0.1 & $<2$ & $<2$ \\
Staphylococcus epidermidis & + & 2.0 & 5.0 & 0.1 & $<2$ & $<2$ \\
Staphylococcus aureus & + & 2.0 & 5.0 & 0.1 & $<2$ & $<2$ \\
Micrococcus kristinae & + & na & 5.0 & 0.1 & $<2$ & $<2$ \\
Streptococcus pyrogens & + & na & na & 0.1 & $<2$ & $<2$ \\
Escherischia coli & - & 2.0 & 5.0 & 0.1 & $<2$ & $<2$ \\
Salmonella pooni & - & na & na & 0.1 & $<2$ & $<2$ \\
Serratia marcescens & - & na & na & 0.1 & $<2$ & $<2$ \\
Pseudomonas aeruginosa & - & na & na & 1.0 & $<2$ & $<2$ \\
Klebsiella pneumonae & - & na & na & 1.0 & $<2$ & $<2$
\end{tabular}

(Faruq et al. 2002, Hassan \& Umar 2006). This is however lower than reported values for Corchorus tridens $(75.0 \% \mathrm{DW})$ and sweet potatoes leaves (82.8\%) (Asibey-Berko \& Tayie 1999). The crude fibre content of A. subfusiformis (21.1\% DW) and $U$. urens (16.1\% DW) is high when compared to Ipomea batatas (7.20\%), T. triangulare $(6.20 \%)$ P. guineensis $(6.40 \%)$, Corchorus olitorius (7.0\%), and Vernonia amygdalina (6.5\%) (Akindahunsi \& Salawu 2005, Antia et al. 2006). Adequate intake of dietary fiber can lower the serum cholesterol level, risk of coronary heart disease, hypertension, constipation, diabetes, colon and breast cancer (Rao \& Newmark 1998, Ishida et al. 2000). The estimated calorific value for $A$. subfusiformis $(285.0 \mathrm{kcal} / 100 \mathrm{~g} \mathrm{DW})$ and $U$. urens (260.9\% DW) leaves compare favourably to $248.8-307.1 \mathrm{Kcal} / 100 \mathrm{~g}$ DW reported in some Nigerian vegetables (Isong et al. 1999, Antia et al. 2006, Akubugwo et al. 2007). Asibey-Berko \& Tayie (1999) also reported comparable energy content in some Ghanaian green leafy vegetables. Thus, confirming that vegetables have low energy values (Lintas 1992).

Macro and micro element analysis: The $\mathrm{Na} / \mathrm{K}$ ratio in the body is of great concern for prevention of high blood pressure. $\mathrm{Na} / \mathrm{K}$ ratio less than one is recommended (FND 2002). Therefore, consumption of A. subfusiformis and $U$. urens would probably reduce high blood pressure diseases because their $\mathrm{Na} / \mathrm{K}$ is less than one. Iron content of leaves of $A$. subfusiformis $(396 \mathrm{mg} / 100 \mathrm{~g})$ and U. urens $(839 \mathrm{mg} / 100$ $\mathrm{g})$ is very high when compared with the value reported in I. batatas $(16.00 \mathrm{mg} / 100 \mathrm{~g}$ ) (Antia et al. 2006). Iron is an essential trace element for haemoglobin formation, normal functioning of the central nervous system and for the oxidation of carbohydrates, protein and fats (Adeyeye \& Otokiti 1999, Akubugwo et al. 2007). The zinc content of $A$. subfusiformis $(72 \mathrm{mg} / 100 \mathrm{~g}$ ) and $U$. urens $(55 \mathrm{mg} / 100 \mathrm{~g})$ compares favourably to most values reported for green leafy vegetables in literatures (Ibrahim et al. 2001, Hassan \& Umar 2006). Zinc is involved in normal function of immune system.

Anti-nutrient analysis: Analysis of the antinutrient contents of the plant showed that alkaloid level in A. subfusiformis $(2.4 \mathrm{mg} / 100 \mathrm{~g}$ ) and $U$. urens $(0.6 \mathrm{mg} / 100 \mathrm{~g})$ is lower than the values reported for the leafy vegetables like Aspilia africana, Bryophyllum pinnatum, Cleome rutidosperma and Emilia coccinea consumed in Nigeria (Edeoga et al. 2006, Okwu \& Josiah 2006, Akubugwo et al. 2007). The levels of saponins in these plants are much less than the value reported for some medicinal plants used in Nigeria. The phytate level in these vegetables is still within the tolerable limits and can easily be detoxified by soaking, boiling or frying (Akubugwo et al. 2007). 
Polyphenols: Polyphenols are the major plant compounds with antioxidant activity. Some of the potential health benefits of polyphenolic substances have been related to the action of these compounds as antioxidants, free radical scavengers, quenchers of singlet and triplet oxygen and inhibitors of peroxidation (Wichi 1988, Li-Chen et al. 2005). As a group, phenolic compounds have been found to be strong antioxidants against free radicals and other reactive oxygen species, the major cause of many chronic human diseases (Kyung-Hee et al. 2005, Chen \& Yen 2007). Phenolic compounds are plant substances which posses in common an aromatic ring bearing hydroxyl substituent. They may occur combined with sugar, as glycosides and they are usually located in the vacuole of the plant cells. The results strongly suggest that phenols are important components of these plants, and some of their pharmacological effects could be attributed to the presence of these valuable constituents. The results from this study showed that the polyphenolic contents of A. subfusiformis in general were higher than those of $U$. urens. The acetone extract of $U$. urens however showed considerably high level of proanthocyanidins. The antioxidant activity of $A$. subfusiformis is relatively greater than that of $U$. urens. This may be due to relatively higher polyphenolic contents of the extracts of $A$. subfusiformis.

Antioxidant activities: The effect of antioxidants on DPPH is thought to be due to their hydrogen donating ability (Yu et al. 2002). The DPPH radical scavenging abilities of the acetone extract of $A$. subfusiformis and $U$. urens at $1 \mathrm{mg} / \mathrm{ml}$ were $92.3 \%$ and $91.2 \%$ respectively, hence slightly less than those of ascorbic acid (99\%) and BHT (99.3\%). This showed that the extracts have the proton-donating ability and could serve as free radical inhibitors or scavengers, acting possibly as primary antioxidants.

Proton radical scavenging is an important attribute of antioxidants. ABTS, a protonated radical, has characteristic absorbance maxima at $734 \mathrm{~nm}$ which decreases with the scavenging of the proton radicals (Yoshida \& Takagi 1999).
At $1 \mathrm{mg} / \mathrm{ml}$ concentration, all the extracts for the two plants produced similar or equal ABTS radical scavenging activity showing that higher concentrations of the extracts were more effective in quenching free radicals in the system. The scavenging of the ABTS radical by the extracts at $1 \mathrm{mg} / \mathrm{ml}$ was found to be higher than that of DPPH radical. Factors like stereoselectivity of the radicals or the solubility of the extract in different testing systems have been reported to affect the capacity of extracts to react and quench different radicals (Zheng \& Wang 2001). Wang et al. (1998) found that some compounds which have ABTS scavenging activity did not show DPPH scavenging activity.

The antioxidant potentials of the leaves extracts of these plants were estimated from their ability to reduce TPTZ-Fe (III) complex to TPTZ-Fe (II). According to recent reports, a highly positive relationship between total phenols and antioxidant activity appears to be the trend in many plant species (Wolfe et al.2003). The acetone and methanol extracts of the two plants had higher ferrous reducing antioxidant power (FRAP) relative to water and BHT, but less activity compared to catechin, ascorbic acid and quercetin. It thus meant that these plants exhibited similar activity.

Antibacterial assay: The high activity shown by the extracts of these two plants may have justified their use for medicinal purposes. The water extract of $U$. urens particularly showed high activity against all the organisms used in this study. The German Commission E approves the use of nettle leaf as supportive therapy in patients with lower urinary tract infections (combined with immune and antimicrobial therapy) and to prevent and treat formation of urinary gravel (Blumenthal et al. 1998). It has also been shown that the plant extracts were active against most of the Gram-positive strains and less of the Gram-negative strains. This observation may have supported the fact that, in general, the Gram-negative bacteria are less susceptible to antibacterial effect than 
the Gram positive ones (Grierson \& Afolayan 1999, Afolayan 2003).

The results of this study showed that the leaves of A. subfusiformis and U. urens contain appreciable amount of proteins, fat, fibre, carbohydrate and calorific value, mineral elements, polyphenols and generally low level of toxicants. Their antioxidant and antibacterial activities further lend credence to the biological value of this plant. Thus, it can be concluded that $A$. subfusiformis and $U$. urens leaves can contribute significantly to the nutrient requirements of man and should be used as supplement nutrients to other major sources. Since these extracts show some activity against some of the organisms used in this study, the use of this plant for medicinal purpose may be justified.

\section{ACKNOWLEDGEMENT}

The authors are grateful to the National Research Foundation (NRF) of South Africa for funding this research.

\section{RESUMEN}

En la actualidad se ha dado un resurgimiento del interés en las plantas silvestres por su posible valor en la dieta, como consecuencia de algunos estudios epidemiológicos que han demostrado efectividad contra importantes enfermedades. En general, los alimentos de origen vegetal contienen muchos compuestos bioactivos, proteínas, energía, vitaminas y minerales específicos; además, las especies silvestres populares proporcionan fibras, ácidos grasos esenciales y aditivos para mejorar el sabor y color de los alimentos. Estudiamos el potencial nutricional y medicinal de las hojas de A. subfusiformis y $U$. urens, recolectados en Alice, Sudáfrica, en noviembre de 2006. Analizamos los compuestos químicos y antioxidantes de estas plantas, la actividad antibacteriana de las hojas en extractos acuosos, con acetona y metanol, utilizando los métodos estándares de análisis. Encontramos que las hojas de ambas especies contienen apreciables porcentajes de humedad, cenizas, carbohidratos, proteínas, lípidos y fibras. El análisis de los macro y microelementos mostró valores altos para $U$. urens en el siguiente orden decreciente: $>$ hierro $>$ manganeso $>$ zinc $>$ cobre $>$ calci o $>$ potasio $>$ nitrógeno $>$ magnesio $>$ fósforo $>$ sodio y para $A$. subfusiformis fue: hierro $>$ zinc $>$ manganeso $>$ cobre $>$ calci o $>$ potasio $>$ nitrógeno $>$ magnesio $>$ fósforo $>$ sodio. Además, la composición química mostró una alta concentración de alcaloides, saponinas y fitatos en A. subfusiformis.
Estos extractos 1, 1 - difenil-2-picrilhidrazil (DPPH) y 2, 2-azinobis-3 ácido etilbenzotiazolina-6-ácido sulfúrico (ABTS) también causaron actividad en el barrido de radicales comparables con los del ácido ascórbico. Los extractos de ambas especies contienen niveles apreciables de polifenoles y también causaron una variada inhibición de algunas cepas bacterianas utilizadas en el estudio. Cuando los nutrientes y compuestos químicos de estas plantas se compararon con los valores dietéticos recomendados (RDA), los resultados revelaron que las hojas contenían una apreciable cantidad de nutrientes, minerales, compuestos químicos y bajos niveles de sustancias tóxicas. Dado que las plantas también mostraron un cierto nivel de actividad antibacteriana, su utilización para fines medicinales en cierta medida está justificada.

Palabras clave: antibacterial, antioxidante, valor nutritional, Argemone subfusiformis, Urtica urens.

\section{REFERENCES}

Adeyeye, E. \& M.K.O. Otokiti. 1999. Proximate composition and some nutritionally valuable minerals of two varieties of Capsicum annum (Bell and cherry peppers). Discov. Innov. 11: 75-81.

Afolayan, A.J. 2003. Extracts from the shoots of Arctotis arctotoides inhibit the growth of bacteria and fungi. Pharm. Biol. 41: 22-25.

Afolayan, A.J. \& J.J.M. Meyer. 1997. The antimicrobial activity of 3,5,7-trihydroxyflavone isolated from the shoot of Helichrysum aureonitens. J. Ethnopharmacol. 57: 177-181.

Agbo, J.T. 2004. Proximate nutrient composition of sickle pod (Cassia obtusfolia) leaves and seeds. Plants Prod. Res. J. 8: 13-17.

Akindahunsi, A.A. \& S.O. Salawu. 2005. Photochemical screening and nutrient-anti-nutrient composition of selected tropical green vegetables. Afr. J. Biotech. 4: 497-501.

Akubugwo, I.E., N.A. Obasi, G.C. Chinyere \& AE. Ugbogu. 2007. Nutritional and chemical value of Amaranthus hybridus L. leaves from Nigeria. Afr. J. Biotech. 6: 2833-2839.

Antia, B.S., E.J. Akpan, P.A. Okon \& I.U. Umoren. 2006. Nutritive and anti-nutritive evaluation of sweet potatoes (Ipomoea batatas) leaves. Pak. J. Nutr. 5: 166-168.

Asibey-Berko, E. \& F.A.K. Tayie. 1999. Proximate analysis of some underutilized Ghanaian vegetables. Ghana J. Sci. 39: 91-92. 
Auld, B.A. \& R.W. Meld. 1992. Weeds an illustrated botanical guide to the weeds of Australia. Inkata, Melbourne, Australia.

Bagchi, K. \& S. Puri. 1998. Free radicals and antioxidants in health and disease. Eastern Mediterranean Health J. 4: 350-360.

Benzie, I.F.F. \& J.J. Strain. 1996. The ferric reducing ability of plasma (FRAP) as a measure of "antioxidant power": the FRAP assay. Anal. Biochem. 239: 70-76.

Berges, R.R., J. Windeler, H.J. Trampisch \& T. Senge. 1998. Randomised, placebo-controlled, double-blind clinical trial of beta-sitosterol in patients with benign prostatic hyperplasia. Beta-sitosterol study Group. Lancet 345: 1529-1532.

Bianco, V.V., P. Santamaria \& A. Elia. 1998. Nutritional value and nitrate content in edible wild species used in Southern Italy. Proceedings 3rd International Society on Diversification of Vegetable Crops. Acta Horticulturae 467: 71-87.

Blumenthal, M., W.R. Busse \& A. Goldberg. 1998. The Complete German Commission E Monographs: Therapeutic Guide to Herbal Medicines. American Botanical Council. Austin, Texas, USA.

Bravo, L. 1998. Polyphenols: chemistry, dietary sources, metabolism, and nutritional significance. Nutr. Rev. 56: $317-333$

Chen, H.Y. \& G.C. Yen. 2007. Antioxidant activity and free radical-scavenging capacity of extracts from guava (Psidium guajava L.) leaves. Food Chem. 101: 689-694.

Duthie, M. 2000. Plant polyphenols in cancer and heart disease: Implications as nutritional antioxidants. Nutr. Res. Rev. 13: 79-106.

Edeoga, H.O., G. Omosun \& L.C. Uche. 2006. Chemical composition of Hyptis sauveolens and Ocimum gratissium hybrids from Nigeria. Afr. J. Biotech. 5: 892-895.

Ekop, A.S. 2007. Determination of chemical composition of Gnetum africana (AFANG) seeds. Pak. J. Nutr. 6: $40-43$

Everist, S.L. 1974. Poisonous plants of Australia. Angus and Robertson, Sydney, Australia.

Faruq, U.Z., A. Sani \& L.G. Hassan. 2002. Proximate composition of sickle pod. (Senna obtusfolia) leaves. Niger J. Basic Appl. Sci. 11: 157-164.
F.N.D. 2002. Food and nutrition board, Institute of medicine. National Academy of Sciences. Dietary reference Intake for energy, carbohydrate, fibre, fat, fatty acids, cholesterol, protein and amino acid (micronutrients).

Green, C. 1992. An overview of production and supply trends in the U.S. specialty vegetable market. Acta Horticulturae 318: 41-45.

Grierson, D.S. \& A.J. Afolayan. 1999. Antibacterial activity of some indigenous plants used for the treatment of wounds in the Eastern Cape, South Africa. J. Ethnopharmacol. 66: 103-106.

Gupta, S., A.J. Lakshmi, M.N. Majunath \& J. Prakash. 2005. Analysis of nutrient and antinutrient content of under utilized green leafy vegetables. L.W.T.-Food Sci. Tech. 38: 339-345.

Harden, G.J. 2002. Flora of New South Wales. University of New South Wales, Sydney, Australia.

Hassan, L.G. \& K.J. Umar. 2006. Nutritional value of Balsam Apple (Momordica balsamina L.) leaves. Pak. J. Nutr. 5: 522-529.

Hirano, T., M. Homma \& K. Oka. 1994. Effects of stinging nettle root extracts and their steroidal components on the $\mathrm{Na}+, \mathrm{K}(+)$-ATPase of the benign prostatic hyperplasia. Planta Med. 60: 30-33.

Hryb, D.J., M.S. Khan, N.A. Romas \& W. Rosner. 1995. The effect of extracts of the roots of the stinging nettle (Urtica dioica) on the interaction of SHBG with its receptor on human prostatic membranes. Planta Med. 61: 31-32.

Huang, Z., B. Wang, D.H. Eaves, J.M. Shikany \& R.D. Pace. 2007. Phenolic compound profile of selected vegetables frequently consumed by African Americans in the southeast United States. Food Chem. 103: 1395-1402.

Ibrahim, N.D.G., E.M. Abdurahhman \& G. Ibrahim. 2001. Elemental analysis of the leaves of Vernonia amygdalina and its biological evaluation in rats. Niger J. Nat. Prod. Med. 5: 13-16.

Ifon, E.T. \& O. Bassir. 1980. The nutritive value of some Nigerian leafy vegetables- parts 2: The distribution of proteins, Carbohydrates (including ethanol-soluble simple sugars), Crude fat, Fibre and Ash. Food Chem. 5: $231-235$.

Ishida, H., H. Suzuno, N. Sugiyama, S.Innami, T. Todokoro \& A. Maekawa. 2000. Nutritional evaluation of chemical component of leaves, stalks and stems of 
sweet potatoes (Ipomea batatas Poir). Food Chem. 68: 359-367.

Isong, E.U., S.A.R Adewusi, E.U. Nkanga, E.E. Umoh \& E.E. Offiong. 1999. Nutritional and phytogeriatological studies of three varieties of Gnetum africanum (afang). Food Chem. 64: 489-493.

Isong, E.U. \& U.I. Idiong. 1997. Comparative studies on the nutritional and toxic composition of three varieties of Leianthera africana. Plants Food Hum. Nutr. 51: 79-84.

Koduru, S., D.S. Grierson \& A.J. Afolayan. 2006. Antimicrobial activity of Solanum aculeastrum. Pharm. Biol. 44: 283-286.

Kyung-Hee, K., T. Rong, R. Yang \& W.C. Steve. 2005. Phenolic acid profiles and antioxidant activities of wheat bran extracts and the effect of hydrolysis conditions. Food Chem. 95: 466-473.

Kumaran, A. \& R.J. Karunakaran. 2006. Antioxidant and free radical scavenging activity of anaqueous extract of Coleus aromaticus. Food Chem. 97: 109-114.

Li-Chen, W., H. Hsiu-Wen, C. Yun-Chen, C. Chih-Chung, L. Yu-In \& A.H. Ja-an. 2005. Antioxidant and antiproliferative activities of red pitaya. Food Chem. 17: 341-346.

Lintas, C. 1992. Nutritional aspects of fruits and vegetable consumption. Options Mediterraennes 19: 79-87.

Liyana-Pathiranan, C.M. \& F. Shahidi. 2003. Antioxidant activity of commercial soft and hard wheat (Triticum aestivum L) as affected by gastric $\mathrm{pH}$ conditions. J. Agric. Food Chem. 53: 2433-2440.

Lockeett, C.T., C.C. Calvert \& L.E. Grivetti. 2000. Energy and micronutrient Composition of dietary and Medicinal wild plants Consumed during drought: Study of Rural Fulani, Northeastern Nigeria. Intl. J. Food Sci. Nutr. 51: 195-208.

Masika, P.J. \& A.J. Afolayan. 2003. An ethnobotanical study of plants used for the treatment of livestock diseases in the Eastern Cape Province, South Africa. Pharm. Biol. 41: 16-21.

Obadoni, B.O. \& P.O. Ochuko. 2001. Phytochemical studies and comparative efficacy of the crude extracts of some homeostatic plants in Edo and Delta States of Nigeria. Global J. Pure Appl. Sci. 8: 203-208.

Ogle, B.M. \& L.E. Grivetti. 1985. Legacy of the chameleon: Edible wild plants in the Kingdom of Swaziland, Southern Africa. A cultural, ecological nutritional study. Part IV: Nutritional analysis and conclusion. Ecol. Food Nutr. 17: 41-64.

Okwu, D.E. \& C. Josiah. 2006. Evaluation of the chemical composition of two Nigerian medicinal plants. Afr. J. Biotech. 5: 357-361.

Ordoñez, A.A.L., J.G. Gomez, M.A. Vattuone \& M.I. Isla. 2006. Antioxidant activities of Sechium edule (Jacq.) Swart extracts. Food Chem. 97: 452-458.

Parsons, W.T. \& E.G. Cuthbertson. 2001. Invasive plant species of the world: A reference guide to environmental weeds. CABI publishing, New York, United States.

Pearson, D. 1976. Chemical analysis of foods. Churchchill, Livingstone, London, England.

Rao, C.V. \& H.L. Newmark. 1998. Chemo-preventive effect of squalene on colon cancer. Carcinogenesis 19: $287-290$.

Re, R., N. Pellegrini, A. Proteggente, A. Pannala, M. Yang \& C. Rice-Evans. 1999. Antioxidant activity applying an improved ABTS radical cation decolorization assay. Free Radical Bio. Med. 26: 1231-1237.

SAS Institute. 1999. SAS language guide for personal computers. SAS Institute, Cary, North Carolina, USA.

Schottner, M., D. Gansser \& G. Spiteller. 1997. Lignans from the roots of Urtica dioica and their metabolites bind to human sex hormone binding globulin (SHBG). Planta Med. 63: 529-532.

Sena, L.P., D.J. VanderJagt, C. Rivera, A.T.C. Tsin, I. Muhammadu, O. Mahammadu, M. Milson, A. Pastosyn \& R.H. Glew. 1998. Analysis of nutritional components of eight famine foods of the Republic of Niger. Plant Foods Hum. Nutr. 52: 17-30.

Sun, J.S., Y.W. Tsuang, I.J. Chen, W.C. Huang, Y.S. Hang, F.J. Lu. 1998. An ultra-weak chemiluminescence study on oxidative stress in rabbits following acute thermal injury. Burns 24: 225-231.

Taylor, R.S.L., F. Edel, N.P. Manandhar \& G.H.N. Towers. 1996. Antimicrobial activity of Southern Nepalese medicinal plants. J. Ethnopharmacol. 45: 67-70.

Wagner, H., F. Willer, R. Samtleben \& G. Boos. 1994. Search for the antiprostatic principle of stinging nettle (Urtica dioica) roots. Phytomed 1: 213-224.

Wang, M., J. Li, M. Rangarajan, Y. Shao, E.J. La Voie, T. Huang \& C. Ho. 1998. Antioxidative phenolic com- 
pounds from Sage (Salvia officinalis). J. Agr. Food Chem. 46: 4869-4873.

Wheeler, V.E. \& F.E. Ferrel. 1971. A method of phytic acid determination in wheat fraction. Cereal Chem. 48: 312-316.

Wichi, H.P. 1988. Enhanced tum from the perspective effect on forestomach and oesophageal squamous epithelium. Food Chem. Toxicol. 26: 717-723.

Wilson, B., D. Hawton \& A.A. Duff. 1995. Crop weeds of northern Australia. Manager Publishing Services, Brisbane, Australia.

Wolfe, K., X. Wu \& R.H. Liu. 2003. Antioxidant activity of apple peels. J. Agric. Food Chem. 51: 609-614.
Yildrim, E., A. Dursun \& M. Turan. 2001. Determination of the nutrition contents of the wild plants used as vegetables in Upper Coruh Valley. Turk. J. Bot. 25: 367-371.

Yoshida, H. \& S. Takagi. 1999. Antioxidative effects of sesamol and tocopherols at various concentrations in oils during microwave heating. J. Sci. Food Agric. 79: 220-226.

Yu, L., S. Haley, J. Perret, M. Harris, J. Wilson \& M. Qian. 2002. Free radical scavenging properties of wheat extracts. J. Agric. Food Chem. 50: 1619-1624.

Zheng, W. \& Y.S. Wang. 2001. Antioxidant activity and phenolic compounds in selected herbs. J. Agric. Food Chem. 49: 5165-5170. 